\title{
Long-Term Grazing Effects on Fescue Grassland Soils ${ }^{1}$
}

\author{
A. JOHNSTON, J. F. DORMAAR, AND S. SMOLIAK
}

Range Ecologist, Soil Scientist, and Range Ecologist, Research Station, Canada Department of Agriculture, Lethbridge, Alberta.

\section{Highlight}

Very heavy grazing of fescue grassland range at Stavely, Alberta, compared to light grazing, changed the color of the Ah horizon from black to dark brown and the $\mathrm{pH}$ from 5.7 to 6.2, reduced the percent organic matter, reduced percent total $P$ but increased $\mathrm{NaHCO}_{3}$-soluble $\mathrm{P}$, and increased soil temperature but decreased percent soil moisture. Trends indicated that soil of the very heavily grazed field was being transformed to a soil characteristic of a drier microclimate.

The importance of soil as a reservoir of nutrients and moisture for the production of foragc has bcen recognized since the beginning of range management as a science (Klemmedson, 1970). With the development of the range condition method of range analysis (Dyksterhuis, 1949; Smoliak et al., 1969), soil became an object of study in terms of soil-plant relations, its potential to produce a vegetative crop, and its resistance to damage. But, in the Fescue Grassland ranges of western Canada, there is still a dearth of soil information for use in management planning and in the improving or rehabilitating of deteriorated or brush-infested ranges.

The purpose of our study was to determine the nature of edaphic change resulting from the grazing of fescue grassland range by cattle.

\section{Materials and Methods}

The study site was at the Canada Department of Agriculture Research Substation, Stavely, Alberta. Vegetation is that of the Fescue Grassland Association (Coupland and Brayshaw, 1953; Moss and Campbell, 1947); soil is a member

\footnotetext{
${ }^{1}$ Received May 2, 1970; accepted for publication August 8, 1970.
}

of the Orthic Black subgroup of the Chernozemic Order and has a clay-loam to loam texture; climate is subhumid, without marked deficiency of precipitation at any season. Annual precipitation averages about $55 \mathrm{~cm}$.

In 1949 the study site was divided into four fields and from 1951 these fields were grazed by cows with calves from about May 15 to November 15 at four rates: light, 0.8 hectares per animal unit month (AUM); moderate, $0.6 \mathrm{ha} / \mathrm{AUM}$; heavy, 0.4 ha/AUM; and very heavy, 0.2 ha/AUM. (After about 1962, because of deterioration of cover, the grazing season on the very heavily grazed field varied from about $2 \frac{1 / 2}{2}$ to 4 months.) Cattle were weighed on and off the grazing fields and at monthly intervals. Percent basal area was determined by the vertical point method. Soil temperatures at a $20-\mathrm{cm}$ depth were obtained by means of 5 Weston thermometers grouped at one location in each field and read at approximately 3-day intervals from May through October. From November through April Brown Type 602 Recording Thermometers were used. Plots were clipped at intervals for yield determinations.

Table 1. Average percentage basal area of vegetation of grazing fields at Stavely, 1949 and 1967.

\begin{tabular}{lcccccc}
\hline & \multicolumn{5}{c}{ Study sites in 1967 by grazing treatments } \\
\cline { 5 - 7 } Species & $\begin{array}{c}\text { Study sites } \\
\text { in } 1949\end{array}$ & Ungrazed Light Moderate Heavy & $\begin{array}{r}\text { Very } \\
\text { heavy }\end{array}$ \\
\hline Danthonia parryi Scribn. & 8.3 & 4.9 & 5.0 & 4.0 & 3.8 & 3.7 \\
Festuca scabrella Torr. & 3.8 & 7.5 & 5.8 & 4.9 & 1.8 & 0.6 \\
Festuca idahoensis Elmer & 1.4 & 0.8 & 1.0 & 1.3 & 1.2 & 2.0 \\
Other grasses & 1.1 & 2.3 & 2.8 & 3.6 & 4.2 & 5.1 \\
Carex sp. & 1.8 & 0.8 & 0.7 & 0.8 & 0.6 & 0.9 \\
Forbs and shrubs & 3.3 & 5.4 & 5.9 & 6.6 & 7.3 & 8.2 \\
\hline
\end{tabular}

In 1967 , ten $15 \mathrm{~m}^{2}$ plots were randomly located in each of the grazing fields (Shantz, 1967). Soil samples were obtained from the Ah horizon of the soil profile of each plot. The following measurements were made: percent basal area of vegetation; soil moisture at a depth of $10-15 \mathrm{~cm}$; average soil temperature at a $15-\mathrm{cm}$ depth based on periodical measurements made during June to September; soil $\mathrm{pH}$ as measured in water (Peech, 1965); percent organic matter (OM), N and total $\mathrm{P}$, and $\mathrm{NaHCO}_{3}$-soluble $\mathrm{P}$ (Atkinson et al., 1958); percent sand and clay; dry soil color (Munsell Color Charts, 1954); slope as expressed in degrees from horizontal; and aspect as expressed in degrees from true north.

\section{Results \\ Vegetation}

Percent basal area of vegetation of ungrazed or lightly grazed fields changed from 1949 to 1967 from dominance by Danthonia parryi Scribn. to dominance by Festuca scabrella Torr. (Table 1). F. scabrella was largely eliminated by very heavy grazing and the field was invaded by various species, including Taraxacum officinale Weber. Change in percent basal area of vegetation was accompanied by a change in yield as grazing became heavier. Plant litter largely disappeared under very heavy grazing.

Estimated average utilization during the period 1951-67, inclu- 
Table 2. Characteristics of Ah horizon of soil from fields grazed at 4 rates for 17 years, Stavely, 1967 (averages of 10 samples*).

\begin{tabular}{lcccccccccc}
\hline \hline $\begin{array}{l}\text { Grazing } \\
\text { treatment }\end{array}$ & $\begin{array}{c}\text { Color } \\
(\mathrm{dry})\end{array}$ & $\begin{array}{c}\text { Sand } \\
(\%)\end{array}$ & $\begin{array}{c}\text { Clay } \\
(\%)\end{array}$ & $\begin{array}{c}\text { Soisture } \\
(\%)\end{array}$ & $\begin{array}{c}\text { Soil tem- } \\
\text { (C) })\end{array}$ & $\begin{array}{c}\mathrm{pH} \\
(\text { water })\end{array}$ & $\begin{array}{c}\text { OM } \\
(\%)\end{array}$ & $\begin{array}{c}\mathrm{N} \\
(\%)\end{array}$ & $\begin{array}{c}\text { Total } \\
\mathbf{P} \\
(\%)\end{array}$ & $\begin{array}{c}\text { NaHCO }_{3^{-}} \\
\text {soluble P } \\
(\mu \mathrm{g} / \mathrm{g})\end{array}$ \\
\hline Light & 10 YR $2 / 1$ & 29 & 30 & $40 \mathrm{a}$ & $13 \mathrm{a}$ & $5.7 \mathrm{a}$ & $11.71 \mathrm{a}$ & $0.59 \mathrm{a}$ & $0.111 \mathrm{a}$ & $2.9 \mathrm{a}$ \\
Moderate & 10 YR $3 / 1$ & 27 & 27 & $37 \mathrm{ab}$ & $15 \mathrm{~b}$ & $5.8 \mathrm{a}$ & $11.23 \mathrm{a}$ & $0.60 \mathrm{a}$ & $0.107 \mathrm{a}$ & $3.5 \mathrm{a}$ \\
Heavy & 10 Y R $3 / 2$ & 30 & 24 & $31 \mathrm{~b}$ & $15 \mathrm{~b}$ & $6.0 \mathrm{ab}$ & $10.74 \mathrm{a}$ & $0.63 \mathrm{a}$ & $0.104 \mathrm{a}$ & $3.5 \mathrm{a}$ \\
Very heavy & 10 YR $3 / 3$ & 30 & 28 & $24 \mathrm{c}$ & $17 \mathrm{c}$ & $6.2 \mathrm{~b}$ & $9.68 \mathrm{a}$ & $0.57 \mathrm{a}$ & $0.099 \mathrm{a}$ & $4.0 \mathrm{a}$ \\
\hline
\end{tabular}

* Means followed by the same letter are not significantly different.

sive, was $20,50,70$, and $90 \%$ of the growth of forage of the current year from each of the light, moderate, heavy, and very heavy grazing treatments.

Populus tremuloides Michx. encroached upon grassland in the lightly and moderatcly grazed ficlds but encroachment was prevented by browsing and trampling in the heavily and very heavily grazed fields.

\section{Soil}

Color of the Ah horizon changed from black (10YR 2/1) under light grazing, to very dark gray $(10 \mathrm{YR}$ $3 / 1$ ) under moderate grazing, to very dark grayish brown (10YR $3 / 2$ ) under heavy grazing, and to dark brown (10YR 3/3) under very heavy grazing (Table 2). There were significant differences among fields in percent soil moisture, soil temperature, and $\mathrm{pH}$. Although differences were not significant, percent $O M$ and percent total $P$ decreased as rate of grazing increased, while $\mathrm{NaHCO}_{3}$-soluble $\mathrm{P}$ increased.

Throughout the year, mean monthly soil temperatures under a light rate of grazing were cooler in summer and warmer in winter than under heavy or very heavy rates of grazing (Table 3). Soil temperature affected the growth of range specics. Spring growth of $F$. scabrella began when the soil temperature at a 20 cm depth reached $3 \mathrm{C}$, that of $D$. parryi at about $5 \mathrm{C}$, and that of Festuca idahoensis Elmer at about 8 C. Dodecatheon conjugens Greene, the flowering of which is used as an indicator of range readiness in the region, reached full bloom at a soil temperature of about 11 C. $F$. scabrella produced fertile culms at a soil temperature of about $13 \mathrm{C}$.

\section{Environmental Relationships}

Simple correlations of 14 environmental factors showed that percent grass cover was negatively correlated with percent forb cover, summer soil temperature, and total $\mathbf{P}$, and positively correlated with percent $\mathrm{OM}$ and percent $\mathrm{N}$ (Table 4). Soil moisture was positively correlated with percent total $P$ and negatively correlated with soil temperature and percent sand in the Ah. Various other relationships among environmental factors are shown.

\section{Animals}

Average annual liveweight gain per hectare increased as rate of grazing increased (Table 5). Amounts of various elements removed by the grazing animals were small in relation to total amounts in the upper $15 \mathrm{~cm}$ of the soil profile.

Table 3. Mean monthly soil temperatures* $\left({ }^{\circ} \mathrm{C}\right)$ at a depth of $20 \mathrm{~cm}$ under 4 grazing fields at Stavely.

\begin{tabular}{lrrrrrrrrrrrr}
\hline \hline \multirow{2}{*}{$\begin{array}{l}\text { Grazing } \\
\text { treatmcnt }\end{array}$} & \multicolumn{1}{c}{ J } & F & M & A & M & J & J & A & S & O & N & D \\
\hline Light & -2 & -1 & -1 & 1 & 5 & 10 & 14 & 13 & 9 & 6 & 2 & -1 \\
Moderate & -6 & -4 & -3 & -1 & 7 & 11 & 16 & 14 & 9 & 6 & 3 & -5 \\
Heavy & -5 & -3 & -2 & -1 & 7 & 12 & 16 & 14 & 10 & 7 & 3 & -4 \\
Very heavy & -5 & -3 & -3 & -1 & 7 & 12 & 17 & 14 & 9 & 7 & 3 & -3 \\
\hline
\end{tabular}

* November-April temperatures recorded during winter, 1964-65; May-October temperatures recorded during summers, 1964-66. 
Table 4. Correlation cocfficients to show relationships among various cnvironmental factors, Stavely, 1967 (n $=40$ ).

\begin{tabular}{|c|c|c|c|c|c|c|c|c|c|c|c|c|c|}
\hline Factor & (2) & (3) & (4) & (5) & (6) & (7) & (8) & (9) & (10) & (11) & (12) & (13) & (14) \\
\hline (1) Grass cover (\%) & $-0.51^{* *}$ & 0.06 & $-0.47^{* *}$ & -0.18 & 0.06 & -0.23 & 0.16 & -0.20 & 0.00 & $0.38^{*}$ & $0.40^{* *}$ & $-0.35^{*}$ & -0.10 \\
\hline (2) Forb cover (\%) & - & 0.16 & 0.14 & -0.11 & 0.06 & 0.20 & -0.22 & 0.27 & -0.02 & -0.13 & -0.17 & 0.00 & 0.05 \\
\hline (3) Soil moisture (\%) & - & - & $-0.61^{* *}$ & -0.12 & -0.08 & 0.28 & $-0.38^{*}$ & 0.09 & $-0.64^{* *}$ & $0.37^{*}$ & 0.24 & $0.47^{* *}$ & -0.08 \\
\hline (4) Soil temperature $(\mathrm{C})$ & - & - & 一 & 0.12 & -0.14 & 0.07 & 0.17 & 0.00 & $0.48^{* *}$ & $-0.32^{*}$ & -0.18 & -0.30 & 0.17 \\
\hline (5) Slope $\left(^{\circ}\right)$ & - & - & 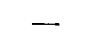 & - & -0.06 & 0.18 & 0.00 & 0.02 & 0.17 & $-0.32^{*}$ & $-0.32^{*}$ & -0.16 & -0.04 \\
\hline (6) Aspect $\left({ }^{\circ}\right)$ & - & - & - & - & - & -0.12 & 0.25 & $0.35^{*}$ & 0.21 & -0.21 & -0.28 & -0.14 & -0.15 \\
\hline (7) Depth of Ah (cm) & - & - & - & - & - & - & -0.25 & 0.06 & -0.17 & -0.10 & -0.14 & 0.27 & -0.23 \\
\hline (8) Sand in Ah (\%) & - & - & - & - & - & - & - & -0.28 & $0.34^{*}$ & -0.16 & -0.01 & -0.30 & -0.03 \\
\hline (9) Clay in Ah (\%) & - & - & 一 & - & - & - & - & - & -0.21 & -0.27 & $-0.57 * *$ & -0.01 & $-0.44 * *$ \\
\hline (10) $\mathrm{pH}$ (water) & - & - & - & - & - & - & - & - & 一 & -0.22 & -0.10 & $-0.44^{* *}$ & $0.42 * *$ \\
\hline (11) OM (\%) & - & - & - & - & - & - & - & - & - & - & $0.70^{* *}$ & 0.03 & 0.06 \\
\hline (12) $\mathrm{N}(\%)$ & - & - & - & 一 & - & - & - & - & - & - & - & 0.00 & $0.34^{*}$ \\
\hline (13) Total P (\%) & - & - & - & - & - & - & - & - & 一 & - & - & - & 0.20 \\
\hline $\begin{array}{l}\text { (14) } \mathrm{NaHCO}_{3} \text {-soluble } \mathrm{P} \\
(\mu \mathrm{g} / \mathrm{g})\end{array}$ & - & - & 一 & - & - & - & - & - & - & - & - & - & - \\
\hline
\end{tabular}

* Significant at $\mathbf{P}<0.05$.

** Significant at $\mathbf{P}<0.01$.

roots. Higher $\mathrm{NaHCO}_{3}$-soluble $\mathbf{P}$ content in the Ah of the very heavily grazed field was probably due to fewer plants being present to use the available P (Table 2).

Hydrologic aspects of soils of the region have been studied. Beke (1969) concluded that, provided the soil was covered by vegetation, type of cover had little influence on water-intake rate and that soils of the region had the capacity to transmit more water than occurred during the maximum recorded stormrainfall intensity. Consumptive use of water by grass or aspen vegetation of the region was similar and averaged for the growing season about $0.30 \mathrm{~cm} /$ day (Singh, $T$., 1970. Personal communication). Johnston (1962) concluded that, as grazing intensity increased, waterintake rate decreased. Soil erosion by water began when about $15 \%$ of the soil surface became bare.

Soil movement as a result of the activities of a burrowing animal, Thomomys lalpoides lalpoides (Richardson), was noted previously on the very heavily grazed field (Shantz, 1967) and an Ah horizon $18 \mathrm{~cm}$ deep was observed downslope. Lutwick and Johnston (1969) noted similar thick Ah horizons in downslope positions and suggested that soil creep within the groundwater discharge zone could account for the formation of the cumulic soils.

Invasion of the lightly and moderately grazed fields by $P$. tremuloides affectcd the character of the soil profile (Beke, 1969; Dormaar and Lutwick, 1966) and soil fertility (Lutwick and Dormaar, 1968). The invasion resulted in the development of a biosequence of soil profiles ranging from Black through Dark Gray Chernozems to Dark Gray Luvisols (Dormaar and Lutwick, 1966) and caused a progressive loss of organic $\mathrm{P}, \mathrm{N}$, and other constituents (Lutwick and Dormaar, 1968).

Our study revealed a similar de-

velopment of a biosequence of soil profiles on the grazed fields. The color of the Ah changed progressively from black under light grazing, to very dark gray under moderate grazing, to very dark grayish brown under heavy grazing, and to dark brown under very heavy grazing (Table 2). The color change did not affect the hue variable (Munsell Soil Color Charts, 1954). The value variable is allied with alterations in parent material associated with amount and distribution of organic matter, which is a function of the climate-vegetation interaction (Buntley and Westin, 1965). Thus, a change in value from 2 to 3 (Table 2) was in agreement with the change in OM, although the latter was not significant. In an

Table 5. Average annual liveweight gain of animals and estimated amounts of some elements removed from the soil of fields grazed at 4 rates for 17 years, Stavely (kg/ha).

\begin{tabular}{lccccc}
\hline \multirow{2}{*}{$\begin{array}{c}\text { Grazing } \\
\text { treatment }\end{array}$} & $\begin{array}{c}\text { Average annual } \\
\text { liveweight gain }\end{array}$ & \multicolumn{4}{c}{ Estimated annual amounts of elements removed } \\
\cline { 4 - 6 } & 42.5 & 1.3 & 0.34 & 0.6 & 0.005 \\
\hline Light & 58.5 & 1.8 & 0.47 & 0.9 & 0.010 \\
Moderate & 78.6 & 2.4 & 0.63 & 1.1 & 0.016 \\
Heavy & 131.6 & 4.0 & 1.05 & 1.9 & 0.026 \\
Very heavy & & & $\mathrm{P}$ & $\mathrm{Ca}$ & \\
\hline
\end{tabular}


orthic profile developed under grassland, chroma generally increases toward the lower horizons. In our study, chroma became brighter as grazing intensity increased, probably reflecting increased use of vegetation and loss of organic matter due to increased grazing pressure, and possibly reflecting increased erosion.

Seventeen years of continuous summer grazing at a very heavy rate changed the soil of the study location. There were indications that the character of soil of the very heavily grazed field was being transformed to that of a drier microclimate. These indications were: a change in color of the $\mathrm{Ah}$ from black to dark brown; a change in $\mathrm{pH}$ from 5.7 to 6.2; lower percent $\mathrm{OM}$; lower percent soil moisture; and higher soil temperature. Previous studies showed that heavy grazing resulted in lower yield of forage, less mulch on the surface, and reduced weight of roots (Johnston, 1961; Johnston, 1962).

The results of our study demonstrate a tenet of range management, that overgrazing of native rangeland results in the creation of an artificial 'droughty' condition in the fields being overgrazed.

\section{Literature Cited}

Atkinson, H. J., G. R. Giles, A. J. Maclean, and J. R. Wright. 1958. Chemical methods of soil analysis. Contrib. 169. Can. Dep. Agr., Chem. Div., Ottawa. 90 p.

Beke, G. J. 1969. Soils of three experimental watersheds in Alberta and their hydrologic significance. Ph.D. thesis. Univ. Alta., Edmonton. $456 \mathrm{p}$.

Buntley, G. J., and F. C. Westin. 1965. A comparative study of developmental color in a ChestnutChernozem-Brunizem soil climosequence. Soil Sci. Soc. Amer. Proc. 29:579-582.

Coupland, R. T., and F. C. BraysHaw. 1953. 'The fescue grassland of Saskatchewan. Ecology 34:386405.

DormaAr, J. F., and L. E. Lutwick. 1966. A biosequence of soils of the rough fescue prairie-poplar transition in southwestern Alberta. Can. J. Earth Sci. 3:457-471.

Dyкsterhuis, E. J. 1949. Condition and management of range land based on quantitative ecology. J. Range Manage. 2:104-115.

Johnston, A. 1961. Comparison of lightly grazed and ungrazed range in the fescue grassland of southwestern Alberta. Can. J. Plant Sci. 41:615-622.

Johnston, A. 1962. Effects of grazing intensity and cover on the water- intake rate of fescue grassland. J. Range Manage. 15:79-82.

KLemmedson, J. O. 1970 . Needs for soil information in the management of range resources. J. Range Manage. 23:139-143.

Lutwick, L. E., and J. F. Dormaar. 1968. Productivity of a soil biosequence of the fescue prairie-aspen transition. J. Range Manage. 21: 24-27.

Lutwick, L. E., AND A. Johnston. 1969. Cumulic soils of the rough fescue prairie-poplar transition region. Can. J. Soil Sci. 49:199-203.

Moss, E. H., and J. A. Campbell. 1947. The fescue grassland of Alberta. Can. J. Res., C 25:209-227.

Munsell Soll Color Charts. 1954. Munsell Color Co., Inc., Baltimore, Md.

NEAL, J. L., JR. 1969. Inhibition of nitrifying bacteria by grass and forb root extracts. Can. J. Microbiol. 15: 633-635.

Peech, M. 1965. Hydrogen-ion activity, p. 914-926. In Black, C. A. (Ed.). Methods of soil analysis. Amer. Soc. Agron. Monogr. No. 9.

Shantz, B. 1967. Rodent-watershed relationships. Project Progr. Rep. 82-5-5-132. Mimeo. Can. Wildlife Serv., Edmonton. 79 p.

Smoliak, S., R. A. Wroe, A. Johnston, AND L, M. Forbes. 1969. Alberta guide to range condition and stocking rates. Alta. Dep. Lands \& Forests, Edmonton. $11 \mathrm{p}$. 